\title{
IDENTIFIKASI DAMPAK DARI JENIS DAN LAMA TERAPI TERHADAP KINERJA FUNGSIONAL TUBUH PADA PASIEN KANKER DENGAN HAND-DYNAMOMETER
}

\author{
Anggun N. A. Murdiyanti ${ }^{1{ }^{1}}{ }^{*}$, Jodelin Muninggar ${ }^{1}$, Nur A. Wibowo ${ }^{1}$ \\ ${ }^{1}$ Program Studi Fisika, Fakultas Sains dan Matematika, Universitas Kristen Satya Wacana, Salatiga 50711, \\ Jawa Tengah
}

*email korespondensi: anggunnurlitasari1@gmail.com

\begin{abstract}
ABSTRAK
Jenis dan lama terapi yang dilakukan pasien kanker berdampak terhadap kinerja fungsional tubuh. Identifikasi dampak dari jenis dan lama terapi terhadap kinerja fungsional tubuh pada pasien kanker telah dilakukan melalui pengukuran kekuatan genggam tangan. Pengukuran kekuatan genggam tangan dilakukan menggunakan handdynamometer. Identifikasi ini merupakan salah satu metode yang valid, sederhana, cepat, mudah dilakukan, tidak menimbulkan efek samping, dan dapat menggambarkan kekuatan seluruh tubuh. Jenis penelitian ini adalah deskriptif kuantitatif dengan sampling pasien kanker di beberapa rumah sakit dan klinik pengobatan herbal di Salatiga yang melakukan terapi pengobatan herbal, operasi, dan campuran. Masing-masing terapi terdiri dari 30 pasien kanker. Metode yang digunakan untuk analisis adalah uji One Way Anova dan Regresi Linier dengan tingkat kebenaran 0,05. Berdasarkan hasil penelitian, dari uji One Way Anova diperoleh nilai signifikansi pada kekuatan maksimal dan ketahanan otot sebesar 0,002 $\mathrm{N}$ dan 0,000 Ns. Hal ini menunjukkan bahwa terdapat dampak yang signifikan antara jenis terapi terhadap kinerja fungsional tubuh pada pasien kanker. Dari uji Regresi Linier diperoleh nilai signifikansi antara lama terapi pengobatan herbal terhadap kekuatan maksimal sebesar 0,087 N, sedangkan nilai signifikansi antara lama terapi pengobatan herbal terhadap ketahanan otot sebesar 0,167 Ns. Kesimpulan menunjukkan bahwa tidak ada dampak yang signifikan dari lama terapi pengobatan herbal terhadap kinerja fungsional tubuh.
\end{abstract}

Kata-kata kunci: fungsional tubuh; Hand-dynamometer; kanker; pasien kanker; terapi

\section{PENDAHULUAN}

Kanker merupakan penyakit tidak menular yang proporsi penderitanya semakin meningkat setiap tahun. Penyakit ini juga menjadi salah satu penyebab utama kematian di seluruh dunia. WHO melaporkan terdapat 11 juta insiden baru mengenai kanker setiap tahunnya di dunia dan diperkirakan insiden ini meningkat menjadi 16 juta kasus baru setiap tahun pada tahun 2020 (Samsarga dkk., 2014).

Seorang yang telah didiagnosis menderita penyakit kanker akan melakukan berbagai pengobatan dan terapi sebagai upaya untuk penyembuhan atau meminimalkan penyebaran sel kanker (Fauziah dan Endang, 2012). Terapi yang sering dilakukan pasien kanker di antaranya kemoterapi, radioterapi, operasi, dan pengobatan herbal (Setiawan, 2015). Jenis dan lama dari terapi-terapi tersebut memiliki efek samping yang bermacam-macam (Melia dkk., 2013; Sehat, 2015; Suardi, 2011). Salah satu dampak yang diduga akan terpengaruh adalah kinerja fungsional tubuh, yaitu kekuatan otot, ketahanan otot, dan massa otot. Kehilangan massa otot dapat menyebabkan penurunan kekuatan otot yang berakibat pada hilangnya fungsionalitas tubuh pada pasien kanker (James and Silk, 2012). Hal ini dapat menyebabkan disfungsi otot secara progresif pada pasien kanker. Disfungsi otot akibat kanker adalah adanya kelainan pada kekuatan otot atau komposisi otot yang terjadi pada pasien kanker (Christensen et al., 2014).

Terganggunya kinerja fungsional tubuh pada pasien kanker dapat diidentifikasi melalui pengukuran kekuatan genggam tangan. Pengukuran kekuatan genggam tangan dapat dilakukan dengan menggunakan hand-dynamometer. Identifikasi ini merupakan salah satu metode yang valid, sederhana, cepat, murah, mudah dilakukan, tidak menimbulkan efek samping, dan dapat menggambarkan kekuatan seluruh tubuh (Nabila dkk., 2017).

Berdasarkan latar belakang yang telah diuraikan, perlu dilakukan penelitian untuk mengetahui dampak dari jenis dan lama terapi terhadap kinerja fungsional tubuh dengan identifikasi melalui kekuatan genggam tangan dari pasien kanker. Penelitian ini bertujuan untuk mengetahui apakah jenis dan lama 
terapi berdampak pada kinerja fungsional tubuh pasien kanker melalui metode identifikasi kekuatan genggam tangan.

Relevansi dari penelitian ini di antaranya adalah dapat diketahuinya keterkaitan antara jenis dan lama terapi yang dilakukan oleh pasien kanker terhadap kinerja fungsional tubuhnya dalam aktivitas dasar hidupnya sehari-hari.

\section{Metode Penelitian}

Jenis penelitian ini berupa penelitian deskriptif kuantitatif dengan pengambilan sampling didasarkan pada tiga jenis terapi di antaranya adalah pengobatan herbal, operasi, dan pengobatan campuran. Masing-masing terapi terdiri dari 30 pasien kanker, sehingga total terdapat 90 pasien.

Penelitian ini dilakukan di beberapa rumah sakit dan klinik pengobatan herbal di Salatiga pada pasien kanker yang melakukan pengobatan rawat jalan di bulan April 2018. Pasien kanker yang melakukan rawat jalan diukur kekuatan genggam tangannya sebelum diperiksa oleh dokter.

Pasien kanker yang menjadi sampel memenuhi kriteria inklusi dan eksklusi. Kriteria inklusi pada penelitian ini di antaranya adalah pernah melakukan terapi kemoterapi/radioterapi/operasi/pengobatan herbal, usia dewasa hingga lansia (20-75 tahun), bersedia mengikuti penelitian, menandatangani lembar persetujuan sebagai responden, dan menggunakan tangan kanan sebagai tangan dominan. Kriteria eksklusi pada penelitian ini adalah pasien kanker dengan fraktur atau edema pada tangan, mengalami gangguan neuromuskuloskeletal atau infeksi lokal, keadaan umum pasien buruk, dan tangan kanan bukan tangan dominan.

Dalam pengambilan data digunakan data primer dan data sekunder. Data primer didapat melalui wawancara pada pasien kanker untuk mengetahui informasi jenis terapi dan lama terapi yang pernah dilakukan serta pengukuran kekuatan genggam tangan pada pasien kanker dengan menggunakan handdynamometer yang terhubung dengan komputer dan aplikasi logger lite. Sedangkan data sekunder didapat melalui rekam medis mengenai riwayat pengobatan kanker. Dalam pengukuran, hand-dynamometer digenggam dengan tangan kanan selama 30 detik sedangkan pasien berada dalam posisi duduk dengan menekuk lengan membentuk siku-siku $90^{\circ}$. Data yang diambil dari pengukuran kekuatan genggam tangan adalah kekuatan maksimal dan ketahanan otot. Keduanya akan digunakan sebagai indikator dari kinerja fungsional tubuh. Data yang diperoleh dikelompokkan berdasarkan jenis dan lama terapi.

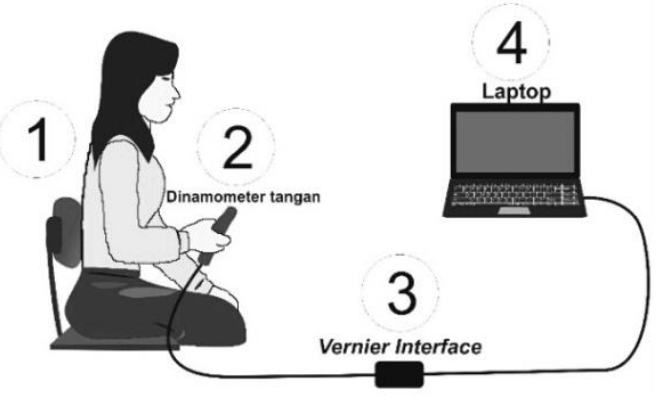

Gambar 1. Proses pengambilan data kekuatan genggam tangan

Dampak dari jenis terapi dan lama terapi terhadap kinerja fungsional tubuh dianalisis dengan uji One Way Anova dan Regresi Linier. Uji One Way Anova dan Regresi Linier dilakukan jika data yang diperoleh memenuhi syarat yaitu harus berdistribusi normal dan berasal dari kelompok yang sejenis (Eka Cania B dan Setyaningrum, 2013). Tingkat kebenaran 0,05 digunakan untuk mengindikasikan nilai signifikansi data yang dihasilkan (Monintja dkk., 2015; Suliyanto, 2011). Pemilihan tingkat kebenaran sebesar 0,05 dilihat dari perlakuan yang diberikan pada pasien kanker tersebut tidak berbahaya.

Metode One Way Anova digunakan untuk menentukan tingkat signifikansi dampak (Pritasari dkk., 2013) dari jenis terapi yang dilakukan terhadap kinerja fungsional tubuh. Sedangkan uji Regresi Linier dilakukan untuk mengetahui hubungan linieritas (Fauziah dan Endang, 2012) dari lama terapi pada pengobatan herbal terhadap kinerja fungsional tubuh. Kedua metode tersebut disajikan seperti alur pada Gambar 1. 


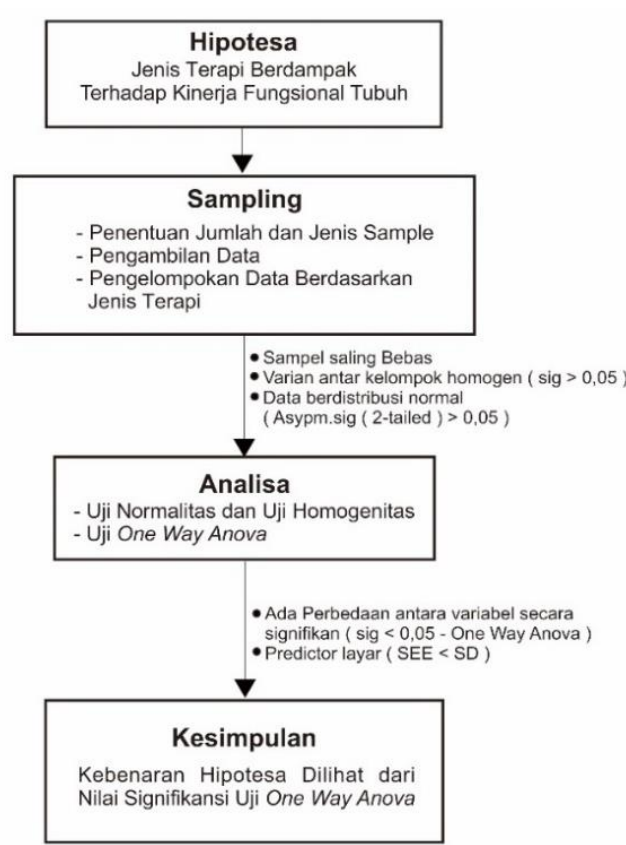

(a)

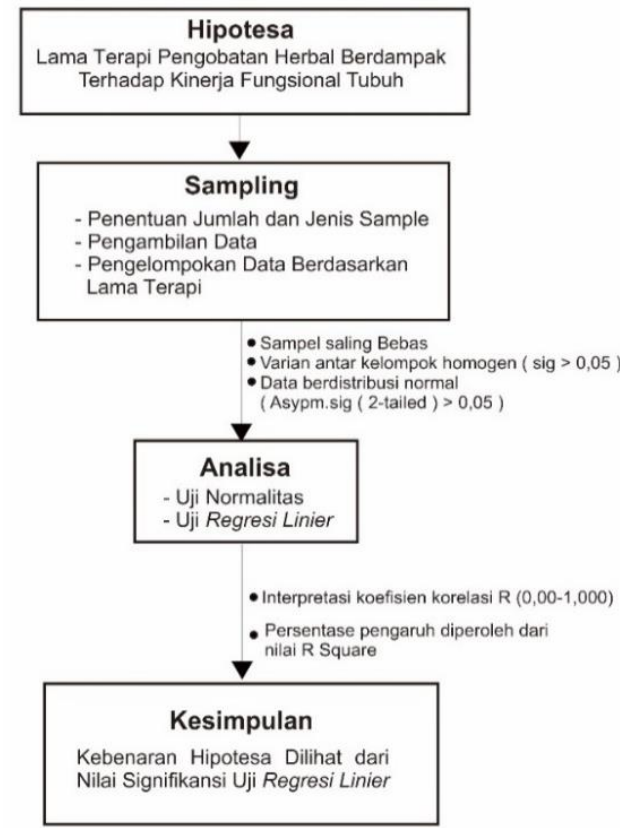

(b)

Gambar 2. Tahapan penelitian (a) Analisis data dengan one way anova, (b) Analisis data dengan regresi linier

\section{HASIL DAN DISKUSI}

Dari hasil pengelompokan sampel didapatkan 90 pasien kanker dengan terapi yang berbeda, 30 pasien melakukan terapi pengobatan herbal, 30 pasien melakukan terapi operasi, dan 30 pasien melakukan terapi campuran. Berdasarkan rekam medik pasien, karakteristik responden penelitian disajikan dalam Tabel 1 berikut:

Tabel 1. Karakteristik Responden

\begin{tabular}{|c|c|c|}
\hline No & Kriteria & Jumlah \\
\hline 1. & Jenis Kelamin & $\begin{array}{l}\text { - } \text { Laki-laki }=15 \text { pasien } \\
\text { - } \quad \text { Perempuan }=75 \text { pasien }\end{array}$ \\
\hline 2. & $\begin{array}{l}\text { Umur (Dewasa- } \\
\text { Lansia) }\end{array}$ & $\begin{array}{ll}\text { - } & 20-35=11 \text { pasien } \\
\text { - } & 36-45=10 \text { pasien } \\
\text { - } & 46-55=27 \text { pasien } \\
\text { - } & 56-65=21 \text { pasien } \\
\text { - } & 66-75=21 \text { pasien }\end{array}$ \\
\hline 3. & Stadium & $\begin{array}{rlrl}\text { - } & & \text { Stadium } 1=63 \text { pasien } \\
\text { - } & \text { Stadium } 2=27 \text { pasien } \\
\text { - } & \text { Stadium } 3=0 \\
\text { - } & \text { Stadium } 4=0\end{array}$ \\
\hline
\end{tabular}

Dalam penelitian ini terdapat dua analisis yang digunakan untuk pemecahan hipotesis, yaitu uji One Way Anova dan uji Regresi Linier.

\section{A. Uji One Way Anova}

Tabel 2. Uji Normalitas One Way Anova

\begin{tabular}{|c|c|c|c|}
\hline & & Kekuatan Maksimal (Newton) & Ketahanan Otot (Newton detik) \\
\hline \multicolumn{2}{|l|}{$\mathrm{N}$} & 90 & 90 \\
\hline \multirow{2}{*}{$\begin{array}{l}\text { Normal } \\
\text { Parameters }{ }^{\mathrm{a}}\end{array}$} & Mean & 94.3872 & $1.7953 \mathrm{E} 3$ \\
\hline & Std. Deviation & $3.47943 \mathrm{E} 1$ & $6.86540 \mathrm{E} 2$ \\
\hline \multirow{3}{*}{$\begin{array}{l}\text { Most Extreme } \\
\text { Differences }\end{array}$} & Absolute & .074 & .111 \\
\hline & Positive & .074 & .111 \\
\hline & Negative & -.056 & -.057 \\
\hline \multicolumn{2}{|c|}{ Kolmogorov-Smirnov Z } & .701 & 1.057 \\
\hline \multicolumn{2}{|c|}{ Asymp. Sig. (2-tailed) } & .709 & .214 \\
\hline
\end{tabular}


Jurnal Sains dan Edukasi Sains, Vol.1, No.2, Agustus 2018: 25-32

Tabel 3. Uji Homogenitas

\begin{tabular}{lcccc}
\hline & Levene Statistic & df1 & df2 & Sig. \\
\hline Kekuatan Maksimal (Newton) & .061 & 2 & 87 & .941 \\
Ketahanan Otot (Newton detik) & 1.530 & 2 & 87 & .222 \\
\hline
\end{tabular}

Dalam uji One Way Anova, data harus berdistribusi normal dan berasal dari kelompok yang sejenis atau homogen (Awang dkk., 2017). Oleh karena itu, diperlukan uji normalitas dan uji homogenitas. Hasil uji normalitas dan uji homogenitas disajikan dalam Tabel 2 dan Tabel 3. Uji normalitas dilakukan dengan menggunakan uji Kolmogorov-Smirnov. Pengambilan keputusan dari uji normalitas dilihat dari nilai yang diperoleh pada kolom Asymp. Sig. (2-tailed). Nilai yang harus dipenuhi adalah >0,05 agar data berasal dari populasi yang berdistribusi normal dan memiliki kelompok yang sejenis (Ulya, 2015). Nilai signifikansi yang di dapat dari uji normalitas terhadap variabel kekuatan maksimal dan ketahanan otot adalah 0,709 $\mathrm{N}$ dan 0,214 Ns. Kedua nilai tersebut lebih besar dari 0,05 $(p>0,05)$ sehingga dapat disimpulkan bahwa data tersebut berdistribusi normal dan memiliki kelompok yang sejenis. Dapat dilihat pula bahwa hasil output dari uji homogenitas memiliki nilai signifikansi sebesar 0,941 $\mathrm{N}$ dan 0,222 $\mathrm{Ns}$ atau $>0,05$. Dengan demikian, nilai tersebut merupakan nilai positif yang menunjukkan data menggerombol dan dapat diasumsikan bahwa data tersebut bersifat homogen (Ulya, 2015). Dari hasil uji normalitas dan uji homogenitas tersebut, syarat karakteristik data telah terpenuhi sehingga dapat dilanjutkan ke tahapan pengujian hipotesis menggunakan One Way Anova.

Tabel 4. Deskripsi Hasil Statistik

\begin{tabular}{|c|c|c|c|c|c|c|c|c|c|}
\hline & & \multirow{2}{*}{$\mathbf{N}$} & \multirow{2}{*}{ Mean } & \multirow{2}{*}{$\begin{array}{c}\text { Std. } \\
\text { Deviation }\end{array}$} & \multirow{2}{*}{ Std. Error } & \multicolumn{2}{|c|}{$\begin{array}{l}\text { 95\% Confidence } \\
\text { Interval for Mean }\end{array}$} & \multirow[b]{2}{*}{ Minimum } & \multirow[b]{2}{*}{ Maximum } \\
\hline & & & & & & $\begin{array}{l}\text { Lower } \\
\text { Bound }\end{array}$ & $\begin{array}{l}\text { Upper } \\
\text { Bound }\end{array}$ & & \\
\hline \multirow{4}{*}{$\begin{array}{l}\text { ekuatan } \\
\text { Maksimal } \\
\text { (Newton) }\end{array}$} & $\begin{array}{l}\text { Pengobatan } \\
\text { Herbal }\end{array}$ & 30 & 1.0205E2 & 31.56085 & 5.76220 & 90.2633 & 113.8333 & 62.33 & 166.70 \\
\hline & Operasi & 30 & $1.0478 \mathrm{E} 2$ & 36.29460 & 6.62646 & 91.2314 & 118.3366 & 48.58 & 211.10 \\
\hline & Campuran & 30 & 76.3293 & 29.86935 & 5.45337 & 65.1759 & 87.4827 & 25.45 & 141.00 \\
\hline & Total & 90 & 94.3872 & 34.79434 & 3.66765 & 87.0997 & 101.6748 & 25.45 & 211.10 \\
\hline \multirow{4}{*}{$\begin{array}{l}\text { Ketahanan } \\
\text { Otot } \\
\text { (Newton } \\
\text { detik) }\end{array}$} & $\begin{array}{l}\text { Pengobatan } \\
\text { Herbal }\end{array}$ & 30 & 1.9617E3 & 577.14268 & $\begin{array}{c}1.05371 \mathrm{E} \\
2\end{array}$ & $\begin{array}{c}1746.158 \\
0\end{array}$ & 2177.1753 & 1159.00 & 3504.00 \\
\hline & Operasi & 30 & 2.0261E3 & 739.55676 & $\begin{array}{c}1.35024 \mathrm{E} \\
2\end{array}$ & $\begin{array}{c}1749.911 \\
6\end{array}$ & 2302.2217 & 1065.00 & 3757.00 \\
\hline & Campuran & 30 & $1.3983 \mathrm{E} 3$ & 565.42136 & $\begin{array}{c}1.03231 \mathrm{E} \\
2\end{array}$ & $\begin{array}{c}1187.154 \\
9\end{array}$ & 1609.4185 & 348.20 & 3068.00 \\
\hline & Total & 90 & $1.7953 \mathrm{E} 3$ & 686.53959 & 72.36763 & $\begin{array}{c}1651.547 \\
1\end{array}$ & 1939.1329 & 348.20 & 3757.00 \\
\hline
\end{tabular}

Deskripsi hasil uji One Way Anova disajikan di dalam Tabel 4. Hipotesis dalam analisis ini adalah jenis terapi berdampak pada kinerja fungsional tubuh pasien kanker. Terapi yang dipilih dalam penelitian ini di antaranya adalah pengobatan herbal, operasi, dan campuran (pengobatan herbal/operasi/kemoterapi/radioterapi). Terapi-terapi ini yang dijadikan sebagai variabel X. Kelayakan dan pemilihan variabel tersebut dapat dilihat dari nilai standart error (SE) dan standart deviation (SD). Terlihat bahwa nilai standart error pada setiap variabel lebih kecil dari nilai standart deviation setiap variabel $(\mathrm{SE}<\mathrm{SD})$. Hasil tersebut menunjukkan bahwa variabel yang digunakan dalam penelitian layak untuk dianalisis. Diperoleh juga bahwa nilai rata-rata (mean) berbeda untuk di setiap variabel terikat. Dilihat dari kategori kekuatan maksimal, ketiga variabel tersebut memiliki nilai rata-rata yang berbeda. Nilai rata-rata untuk variabel pengobatan herbal sebesar 102,05 N, nilai rata-rata untuk variabel operasi sebesar 104,78 N, sedangkan untuk variabel campuran memiliki nilai rata-rata sebesar 76,32 N. Dari kategori ketahanan otot, pengobatan herbal memiliki nilai rata-rata sebesar $1.961,70 \mathrm{Ns}$, operasi memiliki nilai rata-rata sebesar $2.026,10 \mathrm{Ns}$, sedangkan nilai rata-rata untuk campuran sebesar $1.398,80 \mathrm{Ns}$. 
Jurnal Sains dan Edukasi Sains, Vol.1, No.2, Agustus 2018: 25-32

Tabel 5. Hasil Uji One Way Anova

\begin{tabular}{llccccc}
\hline & & Sum of Squares & Df & Mean Square & F & Sig. \\
\hline Kekuatan Maksimal (Newton) & Between Groups & 14786.189 & 2 & 7393.094 & 6.919 .002 \\
& Within Groups & 92961.333 & 87 & 1068.521 & & \\
& Total & 107747.522 & 89 & & & \\
Ketahanan Otot (Newton detik) & Between Groups & 7156521.128 & 2 & 3578260.564 & 8.948 .000 \\
& Within Groups & $3.479 \mathrm{E} 7$ & 87 & 399913.064 & \\
& Total & $4.195 \mathrm{E7}$ & 89 & & \\
\hline
\end{tabular}

Tabel 5 menunjukkan hasil hasil uji One Way Anova. Dari uji tersebut diperoleh nilai signifikansi pada variabel kekuatan maksimal dan ketahanan otot sebesar 0,002 $\mathrm{N}$ dan 0,000 Ns, yang artinya nilai signifikansi dari kedua variabel tersebut $<0,05$. Hal ini menunjukkan bahwa adanya perbedaan rata-rata yang signifikan antara kekuatan maksimal dan ketahanan otot pada pasien kanker yang telah melakukan terapi. Dengan demikian, terdapat dampak yang signifikan antara perlakuan terapi terhadap kinerja fungsional tubuh dari pasien kanker. Hasil ini bersesuaian dengan penelitian yang dilakukan oleh Suardi (2011) bahwa dari setiap jenis terapi akan memiliki dampak terhadap kinerja fungsional tubuh yang berbeda.

\section{B. Uji Regresi Linier}

Tabel 6. Uji Normalitas Regresi Linier

\begin{tabular}{llccc}
\hline & & Lama Terapi (X) (Kali) & $\begin{array}{c}\text { Kekuatan Maksimal } \\
\text { (Y1) (Newton) }\end{array}$ & $\begin{array}{c}\text { Ketahan Otot (Y2) } \\
\text { (Newton detik) }\end{array}$ \\
\hline $\mathrm{N}$ & & 30 & 30 & 30 \\
Normal & Mean & 13.3667 & 102.0483 & 1961.6667 \\
Parameters & Std. Deviation & 7.12685 & 31.56085 & 577.14268 \\
Most & Absolute & .209 & .112 & .122 \\
Extreme & Positive & .209 & .112 & .122 \\
Differences & Negative & -.145 & -.104 & -.082 \\
Kolmogorov-Smirnov Z & 1.147 & .615 & .668 \\
Asymp. Sig. (2-tailed) & .144 & .844 & .764 \\
\hline
\end{tabular}

Sebelum melakukan uji Regresi Linier, dilakukan uji normalitas untuk mengetahui data tersebut berdistribusi normal atau tidak (Suliyanto, 2011). Uji normalitas dilakukan menggunakan teknik perhitungan Kolmogorov-Smirnov. Pengambilan keputusan dari uji normalitas dilihat dari nilai yang diperoleh pada kolom Asymp. Sig. (2-tailed). Suatu data dikatakan berdistribusi normal apabila nilai signifikansi lebih besar dari 0,05 (Field, 2009). Berdasarkan Tabel 6, nilai signifikansi dari lama terapi sebesar 0,144 , nilai signifikansi untuk kekuatan maksimal sebesar 0,844, sedangkan nilai signifikansi untuk ketahanan otot sebesar 0,764. Hal ini menunjukkan bahwa data berdistribusi normal dan dalam kelompok yang sejenis (Ghozali, 2006) sehingga dapat dilanjutkan ke tahap pengujian berikutnya.

Tabel 7. Deskripsi Hasil Statistik

\begin{tabular}{|c|c|c|c|c|c|}
\hline & $\mathbf{N}$ & Mean & Std. Deviation & Minimum & Maksimum \\
\hline Lama Treatment (X) (Kali) & 30 & 13.3667 & 7.12685 & 5.00 & 30.00 \\
\hline Kekuatan Maksimal (Y1) (Newton) & 30 & $1.0205 E 2$ & 31.56085 & 62.33 & 166.70 \\
\hline Ketahanan Otot (Y2) (Newton detik) & 30 & 1.9617E3 & 577.14268 & 1159.00 & 3504.00 \\
\hline
\end{tabular}

Dalam penelitian ini, Uji Regresi Linier digunakan untuk megetahui hubungan linieritas (Fauziah dan Endang, 2012) dari lama terapi pada pengobatan herbal terhadap kinerja fungsional tubuh. Deskripsi hasil uji Regresi Linier disajikan di dalam Tabel 7. Dilihat dari variabel $X$ yaitu lama terapi, nilai rata-rata yang didapat adalah 13,36 , yang artinya dari data yang didapat pasien kanker rata-rata melakukan pengobatan herbal sebanyak 13,36 kali. Selain itu, didapatkan nilai rata-rata untuk kekuatan maksimal (Y1) sebesar $102,05 \mathrm{~N}$, dan nilai rata-rata untuk ketahanan otot (Y2) sebesar 1.961,70 N/s. 
Tabel 8. Koefisien Korelasi

\begin{tabular}{ccccc}
\hline Model & R & \multicolumn{2}{c}{ R Square Adjusted R Square Std. Error of the Estimate } \\
\hline 1 & $.260^{\mathrm{a}}$ & .068 & -.001 & 7.13218 \\
\hline
\end{tabular}

Berdasarkan Tabel 8 terdapat nilai R yang menunjukkan nilai koefisien korelasi. Diperoleh nilai korelasi dari analisis Regresi Linier sebesar 0,260. Hal ini dapat diinterpretasikan bahwa hubungan antara lama terapi terhadap fungsional tubuh ada pada kategori yang lemah (Sungkawa, 2013). Persentase dampak dari lama terapi pengobatan herbal dapat dilihat pada nilai $R$ Square $\left(R^{2}\right)$ (Monintja dkk., 2015). Dari hasil perhitungan $R$ Square $\left(R^{2}\right)$ menunjukkan nilai sebesar 0,068 . Hal ini menunjukkan bahwa lama terapi pengobatan herbal hanya berdampak pada kinerja fungsional tubuh sebesar $6,8 \%$.

Tabel 9. Linieritas Koefisien Korelasi

\begin{tabular}{lccccc}
\hline \multicolumn{1}{c}{ Model } & Sum of Squares & df & Mean Square & F(Newton) & Sig. \\
\hline Regression & 99.531 & 2 & 49.765 & .978 & $.389^{a}$ \\
Residual & 1373.436 & 27 & 50.868 & & \\
Total & 1472.967 & 29 & & & \\
\hline
\end{tabular}

Penentuan taraf signifikansi atau linieritas dari Regresi dapat dilihat pada Tabel 9. Linieritas dampak dari lama terapi terhadap kinerja fungsional tubuh dapat dilihat berdasarkan nilai signifikansinya. Dari hasil analisis diperoleh nilai signifikansi sebesar 0,389 atau > 0,05, yang artinya data tidak berkorelasi secara linier. Suatu data dikatakan linier jika nilai signifikansi lebih kecil dari 0,05 (Fauziah dan Endang, 2012; Field, 2009).

Tabel 10. Hubungan antara variabel $X$ dan variabel $Y$

\begin{tabular}{llccc}
\hline & & $\begin{array}{c}\text { Lama Terapi (X) } \\
\text { (Kali) }\end{array}$ & $\begin{array}{c}\text { Kekuatan Maksimal } \\
\text { (Y1) (Newton) }\end{array}$ & $\begin{array}{c}\text { Ketahanan Otot (Y2) } \\
\text { (Newton detik) }\end{array}$ \\
\hline $\begin{array}{l}\text { Pearson } \\
\text { Correlation (R) }\end{array}$ & Lama Terapi (X)(Kali) & 1.000 & -.255 & -.183 \\
& Kekuatan Maksimal (Y1)(Newton) & -.255 & 1.000 & .826 \\
\cline { 2 - 4 } Sig. (1-tailed) & Ketahanan Otot (Y2) (Newton detik) & -.183 & .826 & 1.000 \\
& Lama Terapi (X)(Kali) &. & .087 & .167 \\
& Kekuatan Maksimal (Y1)(Newton) & .087 &. & .000 \\
N & Ketahanan Otot (Y2)(Newton detik) & .167 & .000 & 30 \\
& Lama Terapi (X)(Kali) & 30 & 30 & 30 \\
& Kekuatan Maksimal (Y1) (Newton) & 30 & 30 & 30 \\
\hline
\end{tabular}

Tabel 10 menunjukkan hubungan antara lama terapi terhadap kekuatan maksimal dan ketahanan otot yang diasumsikan sebagai fungsional tubuh pada pasien kanker. Keterkaitan dari ketiganya dilihat dari nilai signifikasi dari kekuatan maksimal dan ketahanan otot. Berdasarkan tabel tersebut diketahui bahwa korelasi antara lama terapi terhadap kekuatan maksimal $\alpha=0,087 \mathrm{~N} ; \mathrm{R}=-0,255$, tidak signifikan dan memiliki kekuatan korelasi lemah dan berbanding terbalik juga; sedangkan korelasi antara lama terapi terhadap ketahanan otot $\alpha=0,167 \mathrm{Ns}$; $R=-0,183$, tidak signifikan dan memiliki korelasi lemah dan berbanding terbalik juga. Hal ini berarti hipotesis dari penelitian ini ditolak, atau tidak ada dampak dari lama terapi pengobatan herbal terhadap kinerja fungsional tubuh.

\section{KESIMPULAN}

Telah dilakukan penelitian mengenai dampak dari jenis dan lama terapi terhadap kinerja fugsional tubuh pada pasien kanker. Berdasarkan hasil penelitian, dari uji One Way Anova diperoleh nilai signifikansi pada kekuatan maksimal dan ketahanan otot sebesar $0,02 \mathrm{~N}$ dan $0,000 \mathrm{Ns}(<0,05)$. Hal ini menunjukkan bahwa terdapat dampak yang signifikan antara jenis terapi terhadap fungsional tubuh pada pasien kanker. Namun, dari uji Regresi Linier diketahui bahwa nilai signifikansi antara lama terapi terhadap kekuatan maksimal sebesar $0,087 \mathrm{~N}(>0,05)$, dan nilai signifikansi antara lama terapi terhadap ketahanan otot sebesar $0,167 \mathrm{Ns}(>0,05)$. Hal ini menunjukkan bahwa tidak ada dampak dari lama terapi pengobatan herbal terhadap kinerja fungsional tubuh. Nilai koefisien korelasi dari uji Regresi Linier hanya sebesar 0,260, yang 
berarti hubungan antara lama terapi pengobatan herbal terhadap kinerja fungsional tubuh pada kategori yang lemah.

\section{UCAPAN TERIMA KASIH}

Terima kasih kepada rumah sakit dan klinik pengobatan herbal di Salatiga yang telah memberi izin untuk pengambilan sampel penelitian.

\section{DAFTAR PUSTAKA}

Awang, J. K., Pattiserlihun, A., dan Wibowo, N. A. 2017. Pengaruh Profesi Pekerjaan Terhadap Kekuatan dan Daya Tahan Otot Tangan di Kecamatan Sidorejo, Salatiga. Prosiding Lontar Physics Forum IV 2017. Kota Semarang. Sumber: http://prosiding.upgris.ac.id/index.php/LPF2017//pf17/paper/view/1721 [7 Juli 2018]

Christensen, J. F., Jones, L. W., Andersen, J. L., Daugaard, G., Rorth, M., and Hojman, P. 2014. Muscle dysfunction in cancer patients. Annals of Oncology, 25(5): 947-958. Sumber: https://doi.org/10.1093/annonc/mdt551 [13 Juni 2018]

Eka Cania, B. dan Setyanimgrum, E. 2013. Uji Efektivitas Larvasida Ekstrak Daun Legundi (Vitex Trifolia) Terhadap Larva Aedes Aegypti. Jurnal Majority, 2(4). Sumber: http://juke.kedokteran.unila.ac.id/index.php/majority/article/view/62 [23 Juni 2018]

Fauziah, J., dan Endang. 2012. Hubungan Antara Efikasi Diri Dengan Perilaku Mencari Pengobatan Pada Penderita Kanker Payudara di RSUD Ibnu Sina Gresik. Jurnal Psikologi Klinis dan Kesehatan Mental, 1. Sumber: http://journal.unair.ac.id/filerPDF/110810295_13v.pdf [13 Juni 2018]

Field, A. 2009. Discovering Statistics Using SPSS (third edition) (hlm. 1-857). Sumber: https://www.researchgate.net/publication/228079468_Discovering_Statistics_Using_SPSS_third_e dition [7 Juli 2018]

Ghozali, I. 2006. Aplikasi analisis multivariate dengan program SPSS. Badan Penerbit Universitas Diponegoro.

Sumber:

https://books.google.com/books/about/Aplikasi_analisis_multivariate_dengan_pr.html? [22 Juni 2018]

James JPG, G., and Silk, D. 2012. Artificisal Nutrition and Support in Clinical Practice 2nd ed. In: Cuthberson $D J R$, Rennie MJ, editors. Protein and amino acid aetabolism in the whole body and the tissue. Cambrigadge University. Sumber: http://assets.cambridge.org/97811076/09655/frontmatter/9781107609655_frontmatter.pdf [7 Juli 2018]

Melia, E. K. ., Putrayasa, I. D. P. G., dan Azis, A. 2013. Hubungan Antara Frekuensi Kemoterapi Dengan Status Fungsional Pasien Kanker Yang Manjalani Kemoterapi di RSUP Sanglah Denpasar. Sumber: http://download.portalgaruda.org/article.php?article=80896\&val=956 [7 Juli 2018]

Monintja, R. Y., Mandey, S., and Soegoto, A. S. 2015. Brand Analysis, Promotion, and Price Effect on BuyingG Decitonin Supermarkets Gelael Manado. Jurnal EMBA, 3(4): 278-289. Sumber: https://media.neliti.com/media/publications/2822-ID-analisis-merek-promosi-dan-hargapengaruhnya-terhadap-keputusan-pembelian-di-gel.pdf [8 Juni 2018]

Nabila, T., Desiana, and Kurnia, B. 2017. The Relationship of Serum Albumin Levels with Handgrip Strength on Cancer Patients in RSUD dr. Zainoel Abidin Banda Aceh. Jurnal IImiah Mahasiswa Kedokteran Medisia, 2(1). Sumber: http://www.jim.unsyiah.ac.id/FKM/article/view/3186 [9 Juni 2018]

Pritasari, N. F., Parhusip, H. A., dan Susanto, B. 2013. Anova Untuk Analisis Rata-Rata Respon Mahasiswa Kelas Listening. Prosiding SNMPM Universitas Sebelas Maret 2013, 2: 233-315. Sumber: 
https://www.researchgate.net/profile/Hanna_Parhusip/publication/281346679_ANOVA_UNTUK_A NALISIS_RATA-

RATA_RESPON_MAHASISWA_KELAS_LISTENING/links/55e3215f08aecb1a7cc9b63f/[29 Juni 2018]

Samsarga, G.W., Affandi, Y., Utami, N. M. S., Nugraha, I. M. S. S., dan Manuaba, I. B. T. W. 2014. Persepsi Negatif Pasien Kanker Payudara dan Kolorektal Terhadap Kemoterapi dan Radioterapi di Rumah Sakit di Kota Denpasar, Bali. E-Jurnal Medika Udayana, 3(1). Sumber: https://ojs.unud.ac.id/index.php/eum/article/view/11949 [22 Juni 2018]

Sehat, P. 2015. Pasien Sehat. Sumber: http://www.pasiensehat.com//2015/05/pengobatan-kanker-operasikemoterapi-radiasi-html [14 Juni 2018]

Setiawan, S. D. 2015. The Effect Of Chemotherahy In Cancer Patient To Anxiety. Jurnal Majority, 4(4). Sumber: http://juke.kedokteran.unila.ac.id/index.php/majority/article/view/587 [29 Juni 2018]

Suardi, D. R. 2011. Peran dan Dampak Terapi Komplementer/ Alternatif bagi Pasien Kanker. Opini, 38(7). Sumber: http://www.kalbemed.com/Portals/6/34_1880pini\%20Peran\%20dan\%20Dampak\%20Terapi\%20Ko mpementer\%20bagi\%20Pasien\%20Kanker.pdf [9 Juli 2018]

Suliyanto. 2011. Ekonometrika Terapan: Teori dan Aplikasi dengan SPSS. Penerbit Andi. Sumber: http://andipublisher.com/produk-1111004102-ekonometrika-terapan-teori-amp-aplikasi-.html [9 Juli 2018]

Sungkawa, I. 2013. Penerapan Analisis Regresi dan Korelasi Dalam Menentukan Arah Hubugan Antara Dua Faktor Kualitatif Pada Tabel Kontingensi. Jurnal Mat Stat, 13(1): 33-41. Sumber: http://eprints.binus.ac.id/25628/ [13 Juli 2018]

Ulya, H. 2015. Hubungan Gaya Kognitif Dengan Kemapuan Pemecahan Masalah Matematika Siswa. Jurnal Konseling Gusjigang, 1(2). Sumber: https://doi.org/10.24176/jkg.v1i2.410 [10 Juli 2018] 